University for Business and Technology in Kosovo

UBT Knowledge Center

UBT International Conference

2015 UBT International Conference

Nov 7th, 9:00 AM - 5:00 PM

\title{
From Traditional Markets to E-Commerce and Finally to Social Media Commerce
}

Ardian Hyseni

South East European University, ah16609@seeu.edu.mk

Follow this and additional works at: https://knowledgecenter.ubt-uni.net/conference

Part of the Computer Sciences Commons, and the Digital Communications and Networking Commons

\section{Recommended Citation}

Hyseni, Ardian, "From Traditional Markets to E-Commerce and Finally to Social Media Commerce" (2015). UBT International Conference. 83.

https://knowledgecenter.ubt-uni.net/conference/2015/all-events/83

This Event is brought to you for free and open access by the Publication and Journals at UBT Knowledge Center. It has been accepted for inclusion in UBT International Conference by an authorized administrator of UBT Knowledge Center. For more information, please contact knowledge.center@ubt-uni.net. 


\title{
From Traditional Markets to E-Commerce and Finally to Social Media Commerce
}

\author{
Ardian Hyseni \\ Contemporary Sciences and Technologies \\ South East European University, Skopje, Macedonia \\ ah16609@seeu.edu.mk \\ http://www.seeu.edu.mk/
}

\begin{abstract}
These days, getting new customers is much easier than in the past. People and customers are online sharing and exchanging ideas on products and it has become easier to find products over the internet and lately; with social media, where people can look for information from reviews and comments on sites. This way has changed shopping to a social experience and is the key element to the growth of social commerce. Businesses want to connect with people and customers which they do business, also they want customers opinions and reviews. By using social media, companies can now easily create an interaction between the company product and the customer. It is about connecting them customers directly with your website or even making them: from visitors into loyal customers. To fulfill research objectives, it is prepared a questionnaire survey through which we test and analyze the research model and hypothesis. In the conclusion, we discuss about research findings and the future of social media commerce.
\end{abstract}

Keywords: Social Media Commerce, Social Media Commerce Application, Social Media

\section{Introduction}

Social media e-commerce, is a trending way of making business over the internet despite e-commerce that is made by websites nowadays, social media has made it available to buy and sell products, through the social networking sites like Facebook twitter etc. Social media isn't just about posting a feed on Facebook or twitter, or putting a like button or a comment on your website, but it is about connecting customers directly with your website and making them visitors, loyal customers. Back in 1994 when Jeff Bezos founded the Amazon.com and in 1995 Pierre Omidyar started the P2P marketplace on eBay [1]. Both these sites were social networks but these marketplaces were for products with discount prices. Customers could leave feedback, post reviews and comment for the products they bought. This was the new era of commerce through the internet. After eBay and Amazon, in 2004, Facebook was founded by a group of Harvard students. Facebook now is a leading social networking site for a numbers of users, fans and business pages [2].

Businesses want to connect with people and customers which they do business with, and they want customers opinions and reviews [7]. By using social media, companies now can easily create an interaction between company products and the customer. To understand and hear the voice of your customers, businesses need to keep up with the up to date technology. Social media marketing is constantly evolving in sites like: Facebook, Twitter and LinkedIn that are leaders of the online networking, which are the current communication trends [5]. Businesses need to combine new technologies with the traditional marketing, so to increase the sales revenue [3]. Social media is not just another way of marketing, but it must become as part of a company, that should be integrated. It is understandable that businesses should take more seriously the involvement and planning of social media for commercial gain. 
Most of the e-commerce sites have started implementing social media networking site services, in order to improve interaction and increase the active participation of user in order to increase the revenues [4]. In social networking sites, users can get answers and interact with each other, in order to get more information for a specific product or even a service.

When a user wants to order a product online, then may ask and find out more information on the social networking sites. The main aim is to examine and find out at what degree people use social media commerce, and about the impact of social media in peoples' decision making for purchase or in ecommerce.

A social networking site consists of large number of users, which are of the potential content of generators and massive source of information [6]. Users generate new ideas, advertise and add a value at a little cost, while increasing the effectiveness by understanding customer needs, identifying potential customers, and building customer loyalty [11].

The increased number of users in social networks has led to a new shopping trend, where people leverage social networks to make the right purchase. While businesses spend thousands of the money for the marketing which is temporary on a TV station or in the Newspaper, while in social networking sites, people who engage to your page may become lifelong loyal customers [10]. Businesses do not need to pay for advertising in social shopping, they only post products in their business page and all customers are able to see it[8].

\section{Research Methodology}

In the research methodology research questions, hypothesis and survey questions will be presented in order to explore the way which will be taken in order to test and examine the hypothesis and results of the research, and how the data collected and results will be analyzed.

\subsection{Research Methodology}

To test the developed model and hypothesis, it is required an effective research and methodology. It should be considered the conditions, such as research questions, purpose of questions, and the amount of time [9]. Quantitative and qualitative researches are to explain and understand the phenomena. The research can be achieved by analyzing experiences and thoughts of individuals and of groups. Quantitative research questions are the best strategy for gathering data in this surveying case. For this purpose, survey is the best strategy suggested for gathering data and finding the answers. Through survey can get a bigger number of participants for a short period of time.

\subsection{Research Questions}

According to the hypothesis, research questions will be prepared, which will be raised and based on experiences and expectations of participants in this research. In this research, there will be 25 questions; which all of these have its own importance and each question has its own purpose of research. Through these prepared questions, will examine and find answers to the research findings. Results of the answers provided in the survey from participants, will lead us in which social networking site to be focused, for preparing of the application. Questions will be classified through a process from which will lead to the adequate answers and steps to be taken to proceed with the questionnaire. Survey contains three parts of questions. First part contains three questions about participant's educational level, department, and the gender they belong to. Second part contains questions about social media commerce, what knowledge do participants have and what do they think about future of social media commerce. Third part contains questions about measuring; on how much impact does social media have in participant's decision making, and last question about measuring is; how much do participants believe in that social media commerce, will be a leading way of commerce in the future. 


\subsection{Hypothesis}

In this research, three hypotheses are raised that are going to be examined through some questions in the survey that will be taken. Results of this Hypothesis will be after analyzing the data collected from participants in the survey and the questions that are raised will give answers to the hypothesis raised. The hypotheses raised in this research are:

H1. Social media is an integrative part of people's everyday life

H2. Social media e-commerce is a new concept that people are not aware of

H3. Selling and buying through social media is a competitive advantage for companies

H3a. Users spend more time on social media, thus they are influenced by social marketing media

H3b. Active users on social media are more likely to buy if recommended within the platform of their choice

H4b. The Facebook's platform offers advantages of having the customers, thus selling through Facebook is a win-win option for businesses.

By applying the quantitative method of survey questions, we will try to verify these hypotheses in the upcoming chapter.

\subsection{Survey}

After preparing the questions, a survey was posted on Facebook and sent to students with the academic background. Social media remains the best way of sharing information, especially for a research that is being taken. For a few seconds, you can target friends and colleagues or post the survey in the Facebook group of your department or university and will get the answers for a few days to complete the research. The aim of this questionnaire is to collect data, which will be used to describe and see how much people do know about the social media commerce, and how they are informed about this new trending way of commerce; which is in ongoing development. Questions are developed strategically and the questions and its purpose will be shown on the table:

\section{Research findings}

In this section are presented the research findings from survey taken by 100 participants. Participants are from the Republic of Kosovo and Macedonia, mostly of them are students from South East European University, and others are from different Universities around Europe; who are friends and colleagues from different departments. It will be seen from what department are participants and what is the gender participation, education level, and their shopping experience and expectations for social media commerce in the future.

\subsection{Results}

In the research that was taken, 100 students have participated from different educational levels. According to results, it shows that students for Bachelor studies were the bigger number of totally 73, followed by 26 students for Master's degree and only $1 \mathrm{PhD}$. In Table 1 we will see the participants from which department and what gender they belong to. 
International Conference on Computer Science and Communication Engineering, Nov 2015

\begin{tabular}{|c|c|c|c|c|}
\hline & Question & Answers & Participants & $\%$ \\
\hline \multirow{3}{*}{1} & \multirow{3}{*}{ Education level } & Bachelor & 73 & $73 \%$ \\
\hline & & Master & 26 & $26 \%$ \\
\hline & & PHD & 1 & $1 \%$ \\
\hline \multirow{4}{*}{2} & \multirow{4}{*}{ Department } & Economics & 19 & $19 \%$ \\
\hline & & Informatics & 76 & $76 \%$ \\
\hline & & Politics & 4 & $4 \%$ \\
\hline & & Languages & 1 & $1 \%$ \\
\hline \multirow{2}{*}{3} & \multirow{2}{*}{ Gender } & Male & 66 & $66 \%$ \\
\hline & & Female & 34 & $34 \%$ \\
\hline \multirow{2}{*}{4} & \multirow{2}{*}{$\begin{array}{l}\text { Did you do e-commerce } \\
\text { shopping before }\end{array}$} & Yes & 66 & $66 \%$ \\
\hline & & No & 34 & $34 \%$ \\
\hline
\end{tabular}


International Conference on Computer Science and Communication Engineering, Nov 2015

\begin{tabular}{|c|c|c|c|c|}
\hline \multirow{7}{*}{5} & \multirow{7}{*}{$\begin{array}{l}\text { Which social networking sites do } \\
\text { you use? }\end{array}$} & Facebook & 100 & $100 \%$ \\
\hline & & Twitter & 48 & $48 \%$ \\
\hline & & LinkedIn & 44 & $44 \%$ \\
\hline & & Pinterest & 16 & $16 \%$ \\
\hline & & Googlet & 37 & $37 \%$ \\
\hline & & Instagram & 37 & $37 \%$ \\
\hline & & Tumblr & 10 & $10 \%$ \\
\hline \multirow{7}{*}{6} & \multirow{7}{*}{$\begin{array}{l}\text { Which social networking website } \\
\text { do you use most often? }\end{array}$} & Facebook & 84 & $84 \%$ \\
\hline & & Twitter & 4 & $4 \%$ \\
\hline & & LinkedIn & 1 & $1 \%$ \\
\hline & & Pinterest & 0 & $0 \%$ \\
\hline & & Googlet & 1 & $1 \%$ \\
\hline & & Instagram & 10 & $10 \%$ \\
\hline & & Tumblr & 0 & $0 \%$ \\
\hline \multirow{5}{*}{7} & \multirow{5}{*}{ Why do you use social media? } & To play games & 3 & $3 \%$ \\
\hline & & $\begin{array}{l}\text { To find information and share feedback about } \\
\text { brands and products. }\end{array}$ & 46 & $46 \%$ \\
\hline & & $\begin{array}{l}\text { To discover and share new music, books, films, } \\
\text { and other entertainment. }\end{array}$ & 51 & $51 \%$ \\
\hline & & To make professional and business contacts & 58 & $58 \%$ \\
\hline & & To meet new people & 62 & $62 \%$ \\
\hline \multirow{2}{*}{8} & \multirow{2}{*}{$\begin{array}{l}\text { Have you heard about social } \\
\text { media commerce? }\end{array}$} & Yes & 62 & $62 \%$ \\
\hline & & No & 38 & $38 \%$ \\
\hline \multirow{2}{*}{9} & \multirow{2}{*}{$\begin{array}{l}\text { Do you know what is facebook, } \\
\text { commerce? }\end{array}$} & Yes & 49 & $49 \%$ \\
\hline & & No & 51 & $51 \%$ \\
\hline \multirow{4}{*}{10} & \multirow{4}{*}{$\begin{array}{l}\text { What do you think is facebook } \\
\text { commerce? }\end{array}$} & Buying and selling products over ebay & 2 & $2 \%$ \\
\hline & & Buying and selling products over amazon & 1 & $1 \%$ \\
\hline & & Buying and selling products over facebook & 95 & $95 \%$ \\
\hline & & Buying and selling products over alibaba & 2 & $2 \%$ \\
\hline \multirow{2}{*}{11} & \multirow{2}{*}{$\begin{array}{l}\text { Have you ever bought a product } \\
\text { through social networking } \\
\text { websites (Facebook, twitter)? }\end{array}$} & Yes & 9 & $9 \%$ \\
\hline & & No & 91 & $91 \%$ \\
\hline \multirow{2}{*}{12} & \multirow{2}{*}{$\begin{array}{l}\text { Do you have a Facebook } \\
\text { business page? }\end{array}$} & Yes & 36 & $36 \%$ \\
\hline & & No & 64 & $64 \%$ \\
\hline \multirow[b]{2}{*}{13} & \multirow{2}{*}{$\begin{array}{l}\text { Do you know that you can sell } \\
\text { products through your facebook } \\
\text { business page? }\end{array}$} & Yes & 50 & $50 \%$ \\
\hline & & No & 50 & $50 \%$ \\
\hline \multirow[b]{2}{*}{14} & \multirow{2}{*}{$\begin{array}{l}\text { Do you know any Facebook } \\
\text { application that is used for selling } \\
\text { products through Facebook } \\
\text { business pages? }\end{array}$} & Yes & 31 & $31 \%$ \\
\hline & & No & 69 & $69 \%$ \\
\hline \multirow[b]{2}{*}{15} & \multirow{2}{*}{$\begin{array}{l}\text { Do you think that in the future } \\
\text { most of the commerce will be } \\
\text { done through social networking } \\
\text { sites? }\end{array}$} & Yes & 70 & $70 \%$ \\
\hline & & No & 30 & $30 \%$ \\
\hline \multirow{5}{*}{16} & \multirow{5}{*}{$\begin{array}{l}\text { I am more likely to recommend a } \\
\text { product that I saw via social } \\
\text { media (facebooktwyitter)? }\end{array}$} & Strongly Agree & 9 & $9 \%$ \\
\hline & & Agree & 47 & $47 \%$ \\
\hline & & Neutral & 36 & $36 \%$ \\
\hline & & Disagree & 8 & $8 \%$ \\
\hline & & Strongly Disagree & 0 & $0 \%$ \\
\hline
\end{tabular}


International Conference on Computer Science and Communication Engineering, Nov 2015

\begin{tabular}{|c|c|c|c|c|}
\hline \multirow{5}{*}{17} & \multirow{5}{*}{$\begin{array}{l}\text { I am more likely to share my } \\
\text { online shopping experience with } \\
\text { others via social media } \\
\text { (facebooktwitter)? }\end{array}$} & Strongly Agree & 18 & $18 \%$ \\
\hline & & Agree & 35 & $35 \%$ \\
\hline & & Neutral & 32 & $32 \%$ \\
\hline & & Disagree & 10 & $10 \%$ \\
\hline & & Strongly Disagree & 5 & $5 \%$ \\
\hline \multirow{5}{*}{18} & \multirow{5}{*}{$\begin{array}{l}\text { I am more likely to participate in } \\
\text { product discussion through social } \\
\text { networking sites? }\end{array}$} & Strongly Agree & 16 & $16 \%$ \\
\hline & & Agree & 45 & $45 \%$ \\
\hline & & Neutral & 28 & $28 \%$ \\
\hline & & Disagree & 10 & $10 \%$ \\
\hline & & Strongly Disagree & 1 & $1 \%$ \\
\hline \multirow{5}{*}{19} & \multirow{5}{*}{$\begin{array}{l}\text { I am more likely to believe in } \\
\text { quality of product when a } \\
\text { company implements social } \\
\text { media? }\end{array}$} & Strongly Agree & 8 & $8 \%$ \\
\hline & & Agree & 28 & $28 \%$ \\
\hline & & Neutral & 40 & $40 \%$ \\
\hline & & Disagree & 18 & $18 \%$ \\
\hline & & Strongly Disagree & 6 & $6 \%$ \\
\hline \multirow{5}{*}{20} & \multirow{5}{*}{$\begin{array}{l}\text { I trust the quality of product } \\
\text { shared with me by people I know } \\
\text { through social media }\end{array}$} & Strongly Agree & 16 & $16 \%$ \\
\hline & & Agree & 36 & $36 \%$ \\
\hline & & Neutral & 32 & $32 \%$ \\
\hline & & Disagree & 14 & $14 \%$ \\
\hline & & Strongly Disagree & 2 & $2 \%$ \\
\hline \multirow{5}{*}{21} & \multirow{5}{*}{$\begin{array}{l}\text { I trust the quality of product } \\
\text { based on likes and comments } \\
\text { through social media }\end{array}$} & Strongly Agree & 15 & $15 \%$ \\
\hline & & Agree & 39 & $39 \%$ \\
\hline & & Neutral & 32 & $32 \%$ \\
\hline & & Disagree & 15 & $15 \%$ \\
\hline & & Strongly Disagree & 4 & $4 \%$ \\
\hline \multirow{5}{*}{22} & \multirow{5}{*}{$\begin{array}{l}\text { I am more likely to be persuaded } \\
\text { to buy a product by the } \\
\text { information which I get from } \\
\text { social media }\end{array}$} & Strongly Agree & 9 & $9 \%$ \\
\hline & & Agree & 41 & $41 \%$ \\
\hline & & Neutral & 37 & $37 \%$ \\
\hline & & Disagree & 13 & $13 \%$ \\
\hline & & Strongly Disagree & 0 & $0 \%$ \\
\hline \multirow{5}{*}{23} & \multirow{5}{*}{$\begin{array}{l}\text { I think social media commerce } \\
\text { will be a leading way of } \\
\text { commerce in the future }\end{array}$} & Strongly Agree & 16 & $16 \%$ \\
\hline & & Agree & 47 & $47 \%$ \\
\hline & & Neutral & 33 & $33 \%$ \\
\hline & & Disagree & 2 & $2 \%$ \\
\hline & & Strongly Disagree & 2 & $2 \%$ \\
\hline
\end{tabular}

\subsection{Hypothesis results}

Comparing findings and results of the hypotheses test, 2 of our hypotheses were supported and 1 was not. First hypotheses were:

H1. Social media is an integrative part of people's everyday life. It is and people are not only the users, but have become addicted to social media. In figure 1.7 it is shown that social media is not just a part of entertaining, but also for buying and selling, product discussions and can be used for creating of professional and business contacts.

H2. Social media commerce is a new concept that people are not aware of, according to Figure 1.8; surprisingly $62 \%$ of our participants claim that have heard the term social media commerce, but only $9 \%$ of participants have bought products through social media commerce.

H3. Selling and buying through social media is a competitive advantage for companies, and it is supported. $70 \%$ of the participants believed that social media commerce will be a leading way of commerce in the future, according to Figure 1.15. This shows that most of the participants believe in the social media commerce and companies who apply social media commerce, have or will have advantage over companies who don't.

H3a. Users spend more time on social media, thus they're influenced by social media marketing.

This is completely supported by participants according to Figure 1.20 , more than $50 \%$ agree that 
if a product is recommended or commented positively by participants, they would be persuaded to buy a product.

H3b. Active users on social media, are more likely to buy if recommended within the platform of their choice. According to Figure 1.22 it is supported that the more time people spend in social media the more they are persuaded to buy, if a product is recommended by a friend most of the participants agree to buy.

H4b. Facebook's platform offers advantages of having customers, thus selling through Facebook is a win-win option for businesses. According to Figure 1.21, it is an advantage if a company uses Facebook for selling; hash tags makes it possible that one product to be seen by how many people have chosen hash tag. Social media offers marketing for free and everyone can access it from everywhere.

\section{Conclusion}

Generally social media commerce is an emerging shopping trend that is increasing significantly. So many apps for selling products through social networking sites are developed for a very short time. Based on the previous years the rise of social commerce it tends to be the leading way of commerce in the coming years.

Finally, based on the research and the app that is developed. It can be concluded that research will have positive impact in people's daily life in all aspects of entertaining and shopping experiences. It can be concluded that Facebook users have a lots of fun, while sharing and writing feedbacks about product and making purchases. Application that is developed for purpose of this thesis tends to be a good app for small businesses who want to sell products through Facebook.

\section{References}

1. Social Media Explained Untangling the World's Most Misunderstood Business Trend Mark W. Schaefer

2. Collier, Marsha (2012-11-08). Social Media Commerce For Dummies (Kindle Locations 1-2). Wiley. Kindle Edition.

3. Varela, C. (2015-02-03). Facebook Marketing for Business: Learn to create a successful campaign, Advertise your Business, Strategies to generate traffic and Boost sales (Social Media)

4. The Effects of Social Media on E-commerce: A Perspective of Social Impact Theory 2012 45th Hawaii International Conference on System Sciences

5. Facebook for Business Owners: Facebook Marketing For Fan Page Owners and Small Businesses (Social Media Marketing) (Volume 2) Corson-Knowles, Tom

6. Why We Buy: The Science of Shopping--Updated and Revised for the Internet, the Global Consumer, and Beyond Underhill, Paco

7. The Social Media Bible: Tactics, Tools, and Strategies for Business Success Safko, Lon

8. E-business and e-commerce management: strategy, implementation, and practice / Dave Chaffey. -- 4th ed.

9. Social Commerce Research: An integrated view. Lina Zhou, Ping Zhang and Hans-Dieter Zimmermann Last revised: February 15, 2013

10. The Effects of Social Media on E-commerce: A Perspective of Social Impact Theory $\mid 2012$ 45th Hawaii International Conference on System Sciences 
International Conference on Computer Science and Communication Engineering, Nov 2015

11. The Effects of Social Media on E-commerce: A Perspective of Social Impact Theory: KeeYoung Kwahk, Xi Ge 